\title{
Hemochromatosis Gene Polymorphism as a Predictor of Sustained Virological Response to Antiviral Treatment in Egyptian Chronic Hepatitis C Patients
}

\author{
${ }^{1}$ Mai I Mehrez, ${ }^{2}$ Dina SA Fattah, ${ }^{3}$ Naglaa AA Azeem, ${ }^{1}$ Mohamed A Saleh, ${ }^{3}$ Khadiga M Mostafa \\ ${ }^{1}$ Department of Hepatology, National Hepatology and Tropical Medicine Institute, Cairo, Egypt, ${ }^{2}$ Department of Medical Biochemistry \\ and Molecular Biology, Cairo University, Cairo, Egypt, ${ }^{3}$ Department of Medical Biochemistry, Beni Suef University, Beni Suef, Egypt
}

\begin{abstract}
Aim: The aim of this article is to assess HFE C282Y gene mutations as a predictor of sustained virological response (SVR) to anti-hepatitis $\mathrm{C}$ virus (HCV) treatment in Egyptian patients.

Materials and methods: One hundred and forty chronic hepatitis $\mathrm{C}(\mathrm{CHC})$ patients were divided into two groups: 70 patients achieved SVR and 70 patients were nonresponders (NRs). All patients were subjected to quantitative polymerase chain reaction (PCR) at baseline, 12 and 24 weeks after therapy commencement. Deoxyribonucleic acid (DNA) sequencing for HFE (C282Y) was done by restriction fragment length polymorphism PCR.

Results: Sixty five patients did not have mutation and 5 patients had C282Y mutation (GA) with SVR. While 45 NRs had heterozygous C282Y mutation (GA), 4 patients $(5.7 \%)$ had homozygous mutation $(A A)$ and 21 patients $(30 \%)$ had no mutation (GG). The parameters of elevated iron [transferrin saturation (TS; $p<0.001)$, S iron $(p<0.02)$, total iron binding capacity (TIBC; $p<0.001)$, transferrin $(p<0.016)$, and soluble transferrin receptor (sTfR; p-value, 0.001)] were significantly associated with C282Y mutation. However, there was no significant difference regarding ferritin values and C282Y mutation in NR patients.

Conclusion: Iron overload was frequently detected in $\mathrm{CHC}$ patients and associated with $\mathrm{C} 282 \mathrm{Y}$ mutation, while biochemical markers of iron overload and C282Y HFE mutation were negative prognostic factor.
\end{abstract}

Keywords: Antiviral treatment, Hemochromatosis gene polymorphism, Polymerase chain reaction.

How to cite this article: Mehrez MI, Fattah DSA, Azeem NAA, Saleh MA, Mostafa KM. Hemochromatosis Gene Polymorphism as a Predictor of Sustained Virological Response to Antiviral Treatment in Egyptian Chronic Hepatitis C Patients. Euroasian J Hepato-Gastroenterol 2017;7(2):154-157.

Source of support: Nil

Conflict of interest: None

\section{INTRODUCTION}

The World Health Organization has declared hepatitis $\mathrm{C}$ as a global health problem, with approximately $3 \%$ of the world's population infected with $\mathrm{HCV}^{1}$ Egypt has the highest prevalence of $\mathrm{HCV}$ in the world at 12 to $13 \% .^{2}$ Approximately $20 \%$ of blood donors are HCV Ab positive. ${ }^{3}$ Iron overload in the liver induces oxidative stress, which was a factor of cell membrane damage, DNA instability, and mutagenesis. Due to these effects, iron can be considered a proinflammatory, profibrogenic factor, and a potential carcinogen. Since the implementation of serological diagnostic tests for HCV identification, elevated serum iron overload indices or appearance of iron deposits in liver cells have been observed in 10 to
$40 \%$ of patients with $\mathrm{CHC}$ and $50 \%$ of patients suffering both from CHC and hepatocellular carcinoma. ${ }^{4}$ Some investigations have shown an association between elevated serum iron indices or high hepatic iron concentration (HIC) and the lack of SVR in CHC patients, ${ }^{5}$ whereas others have shown that there is no positive correlation between HIC and decreased frequency of SVR. ${ }^{6}$ In 2006, Bonkovsky et $\mathrm{al}^{7}$ found the presence of iron in endothelial cells with triad iron score (not global iron score) as a predictor of decreased SVR. These contradictory results from different parts of the world may possibly have their source in ethnic differences and the variable polymorphisms of iron metabolism-related genes found in different populations. The aim of this 
work is to assess the value of HFE C282Y gene mutations as a predictor of SVR to antiviral treatment in Egyptian patients with $\mathrm{CHC}$ virus infection.

\section{MATERIALS AND METHODS}

The study was conducted on 140 CHC patients (based on the presence of persistently elevated liver enzymes for at least 6 months and detection of HCV ribonucleic acid by PCR technique) who took antiviral treatment. The patients were divided into two groups: Group I consisted of 70 patients who achieved SVR after antiviral treatment, and group II consisted of 70 patients who did not respond to antiviral treatment (NR). Patients with malignancy, decompensated cirrhosis, hepatitis B virus coinfection, or other causes of liver disease were excluded. All patients were subjected to full history taking, clinical examination, laboratory investigations including liver and kidney biochemical profile, alfa fetoprotein (AFP), viral load, and specific tests of our study: Complete iron profile, molecular study for HFE (C282Y).

\section{RESULTS}

The data about patient profiles are shown in Table 1. As regards age and sex, there was no statistically significant difference between SVR and NR groups (with p-value 0.140 and 0.091 respectively). Also, the whole liver profile did not show any statistically significant difference. A high statistically significant difference was observed between NR and SVR regarding GG, GA, and AA genotype, which was absent in SVR group (Table 2). Sustained virological response was associated with allele A and NR was associated with allele G (Table 2). Concerning iron status, there was statistically significant difference between SVR and NR groups regarding different parameters of iron levels [S iron, TIBC, transferrin, TS \% and sTfR)]. However, no statistical significance was documented for $\mathrm{S}$ ferritin between the two groups (Table 3).

\section{DISCUSSION}

Chronic hepatitis $\mathrm{C}$ patients have frequently elevated serum iron stores and elevated HIC, which has been

Table 1: Comparison between responder and NR group

\begin{tabular}{|c|c|c|c|c|}
\hline & & & & ders \\
\hline & Range & Mean $\pm S D$ & Range & Mean $\pm S D$ \\
\hline Age (years) & $20-59$ & $43.7 \pm 9.1$ & $21-59$ & $46.0 \pm 8.8$ \\
\hline Blood sugar & $60-266$ & $105.5 \pm 33.2$ & $10-197$ & $99.2 \pm 24.8$ \\
\hline Creatinine & $0.2-1.4$ & $0.9 \pm 0.2$ & $0.6-1.4$ & $0.9 \pm 0.2$ \\
\hline Albumin & $3.5-5.1$ & $4.2 \pm 0.4$ & $3.5-5.7$ & $4.1 \pm 0.4$ \\
\hline ALP & $3.7-314$ & $133.2 \pm 79.8$ & $11-380$ & $122.9 \pm 54.2$ \\
\hline AST & $11.7-247$ & $60.9 \pm 39.2$ & $7-226$ & $58.4 \pm 41.8$ \\
\hline ALT & $12-260$ & $66.4 \pm 42.4$ & $4-195$ & $64.6 \pm 42.6$ \\
\hline T.Bil. & $0.16-1.8$ & $0.8 \pm 0.3$ & $0.35-1.6$ & $0.8 \pm 0.3$ \\
\hline D.Bil. & $0.1-1.2$ & $0.4 \pm 0.3$ & $0.1-1.1$ & $0.4 \pm 0.2$ \\
\hline TLC & $3.1-12$ & $6.0 \pm 1.8$ & $3.1-10.2$ & $6.3 \pm 1.8$ \\
\hline $\mathrm{HB}$ & $11-18.9$ & $14.2 \pm 1.8$ & $11-17$ & $13.6 \pm 1.4$ \\
\hline PLAT & $112-417$ & $212.5 \pm 66.6$ & $110-345$ & $210.9 \pm 61.2$ \\
\hline PC & $60-100$ & $85.2 \pm 10.8$ & $60-100$ & $85.2 \pm 10.7$ \\
\hline AFP & $0.4-162$ & $11.2 \pm 21.0$ & $0.5-43$ & $6.7 \pm 6.8$ \\
\hline S. iron ( $\mu \mathrm{g} / \mathrm{dL})$ & $38-90$ & $56.76 \pm 9.95$ & $32-90$ & $52.5 \pm 11.1$ \\
\hline TIBC $(\mu \mathrm{g} / \mathrm{dL})$ & $104-296$ & $172.44 \pm 39.72$ & $123-410$ & $205.3 \pm 59.29$ \\
\hline S. ferritin $(\mathrm{g} / \mathrm{mL})$ & $91-310$ & $158.19 \pm 41.32$ & $91-274$ & $156.37 \pm 36.24$ \\
\hline Transferrin (mg/dL) & $89-410$ & $239.23 \pm 76.95$ & $113-340$ & $211.23 \pm 57.43$ \\
\hline TS $\%$ & $18-61.6$ & $34.5 \pm 10.14$ & $9-45$ & $27.48 \pm 9.32$ \\
\hline sTfR (nmol/L) & $11.20-36$ & $18.10 \pm 6.75$ & $11.2-18$ & $13.91 \pm 1.49$ \\
\hline
\end{tabular}

SD: Standard deviation; ALP: Alkaline phosphatase level; AST: Aspartate aminotransferase; ALT: Analine aminotransferase;

T.Bil: Total bilirubin; D.Bil: Direct bilirubin; TLC: Total leukocyte count; HB: Hemoglobin; PLAT: Plasminogen activator

Table 2: Frequency of the genotypes of gene polymorphisms and allele frequency and OR in responder vs NR group

\begin{tabular}{|c|c|c|c|c|c|c|c|}
\hline & & \multicolumn{2}{|c|}{ Nonresponders } & \multicolumn{2}{|c|}{ Responders } & \multirow[b]{2}{*}{$p$-value } & \multirow[b]{2}{*}{ OR $(95 \% \mathrm{Cl})$} \\
\hline & & Count & $\%$ & Count & $\%$ & & \\
\hline \multirow[t]{3}{*}{ HFE } & AA & 4 & 5.7 & 0 & 0 & 0.12 & \\
\hline & GA & 48 & 64.3 & 5 & 7.1 & $<0.001$ & $23.4(8.33-65.72)$ \\
\hline & GG & 21 & 30 & 65 & 92.9 & $<0.001$ & $0.033(0.012-0.094)$ \\
\hline \multirow[t]{2}{*}{ Allele } & A & 53 & 37.9 & 5 & 3.6 & $<0.001$ & $27.414(8.307-90.47)$ \\
\hline & G & 87 & 62.1 & 135 & 96.4 & & \\
\hline
\end{tabular}

OR: Odds ratio 
Table 3: Comparison between responder and NR group as regards iron study

\begin{tabular}{|c|c|c|c|c|}
\hline & Nonresponders Mean $\pm S D$ & Responder Mean $\pm S D$ & $p$-value & Significant \\
\hline S. iron $(\mu \mathrm{g} / \mathrm{dL})$ & $56.76 \pm 9.95$ & $52.56 \pm 11.10$ & 0.020 & $\mathrm{~S}$ \\
\hline TIBC $(\mu \mathrm{g} / \mathrm{dL})$ & $172.44 \pm 39.72$ & $205.30 \pm 59.29$ & $<0.001$ & HS \\
\hline Transferrin saturation $\%$ & $34.50 \pm 10.14$ & $27.48 \pm 9.32$ & $<0.001$ & HS \\
\hline S. ferritin (ng/mL) & $158.19 \pm 41.32$ & $156.37 \pm 36.24$ & 0.783 & NS \\
\hline Transferrin (mg/dL) & $239.23 \pm 76.95$ & $211.23 \pm 57.43$ & 0.016 & HS \\
\hline $\mathrm{sTfR}(\mathrm{nmol} / \mathrm{L})$ & $18.10 \pm 6.75$ & $13.91 \pm 1.49$ & $<0.001$ & HS \\
\hline
\end{tabular}

SD: Standard deviation; S: Significant; HS: Highly significant; NS: Nonsignificant

associated with a poor response to interferon-alfa. ${ }^{8}$ The mechanism by which iron accumulates in liver infected with chronic HCV has not yet been established. Serum iron and ferritin levels were increased in patients with $\mathrm{CHC}$ because of their release from hepatocellular stores in association with cell necrosis. ${ }^{9}$ Individuals with serum iron levels in the upper range of normal as a result of genetic polymorphisms or a high iron diet may be predisposed to develop more severe chronic HCV infections. ${ }^{9}$ Several studies ${ }^{10}$ have found that heterozygous C282Y mutations are associated with hepatic iron loading in $\mathrm{CHC}$ patients. Iron overload seems to impair antigen-specific immune responses by decreasing the generation of $\mathrm{T}$ cells and by impairment of natural killer and $\mathrm{T}$ helper cell function. Piperno et $\mathrm{a}^{11}$ suggested that iron overload in patients with hemochromatosis may contribute to the persistence of $\mathrm{HCV}$ infection, and iron overload may in theory promote viral replication. The amount of hepatic iron has been identified as one of these factors that adversely affect the likelihood of response to interferon-alfa; those patients with higher hepatic iron content are less likely to respond to interferon therapy. ${ }^{12}$ In our study, there was a correlation between HFE gene mutation and iron overload. We considered transferrin saturation index (TSI) as the most specific and sensitive parameter in identifying iron overload as it showed a significant statistical difference between responder group $(27.5 \%)$ and NR $(34.5 \%)$ group with p-value $<0.001$. But there was no significant difference for serum ferritin, $S$ iron $(p=0.02)$, TIBC $(p>0.001)$ transferrin $(\mathrm{p}=0.016), \operatorname{sTfR}(\mathrm{p}>0.001)$, but our study provides evidence supporting that the HFE gene mutations are associated with significant abnormalities of iron metabolism and suggests that patients with $\mathrm{CHC}$ accumulate iron as a result of interplay between genetic and acquired factors. We noticed that A allele is associated with higher iron parameters and lower TIBC and the homozygous mutation (AA) is associated with higher iron indices. The wildtype (GG) is lower than the heterozygous mutation (GA) genotype. There is a statistically significant difference between gene polymorphism (AA, GA, GG) and iron parameters with $p$-value $<0.001$ for each of $S$. iron, TIBC, TS\%, and S. ferritin, with p-value 0.033 as regarding transferrin and by 0.026 as regarding sTfR. Sustained virological response rates were lower among patients with HFE gene mutations compared with those with HFE gene wildtype. In our study, 54 of $140(38.5 \%)$ patients have mutation [50 heterozygous (GA) and 4 homozygous (AA)] and 86 have no mutation (wild-type GG). All homo and 45 from heterozygous mutation did not respond to treatment; $92 \%$ (92.9\%) of the SVR group have no (GG) mutation and 7\% carry C282Y mutation (GA), while $64.3 \%$ of NR group carry heterozygous $\mathrm{C} 282 \mathrm{Y}$ mutation (GA), 5.7\% carry homozygous mutation (AA), and $30 \%$ are without mutation (GG). Therefore, HFE gene mutations may act synergically with $\mathrm{CHC}$ in the development of liver damage, predicting a higher rate of nonresponse to therapy. Our results correlate with those of Sini et al, ${ }_{13}^{13}$ who stated that $69 \mathrm{CHC}$ patients with endof-treatment response were lower among patients with HFE gene mutations compared with those with HFE gene wildtype $(p=0.005)$ and TSI showed a significant statistical difference between HFE mutant patients (50\%) and wild-type homozygotes $(43.4 \%)(\mathrm{p}<0.01)$. CoelhoBorges et $\mathrm{a}^{14}$ had similar results in 2002 when they studied 44 Brazilian patients. They showed that SVR was achieved in 0 of 16 patients with HFE gene mutations and $11(41 \%)$ of 27 patients without HFE gene mutations ( $p=$ 0.002). They concluded that heterozygosity for H63D and/ or C282Y HFE gene mutation predicted absence of SVR to combination treatment with interferon and ribavirin in patients with $\mathrm{CHC}$, non-1 genotype and serum ferritin levels above $500 \mathrm{ng} / \mathrm{mL}$. Our results did not correlate with those of Li et al, ${ }^{15}$ who showed that H63D mutation was associated with a significantly higher SVR rate [odds ratio $(\mathrm{OR})=1.60,95 \%$ confidence interval $(\mathrm{CI}): 1.09-2.34$, $\mathrm{p}=0.020]$, while the $\mathrm{C} 282 \mathrm{Y}$ mutation was not $(\mathrm{OR}=1.19$, $95 \%$ CI: $0.71-1.98, p=0.510$ ). We do not agree with Lebray et $\mathrm{al}^{16}$ who based on a large cohort of HCV-infected patients found an opposite effect of iron blood parameters and the H63D mutation on the antiviral efficacy of interferon-alfa used alone or in combination therapy with exception of six C282Y heterozygote patients that displayed no sustained response; but this group was too small to allow the detection of a significant difference with any other group. Increased iron stores may affect the 
course of viral infection in various ways: First, increased HIC may facilitate viral replication and in vitro data suggest that iron facilitates HCV replication in cultured hepatocytes. ${ }^{17}$ Second, iron loading was demonstrated to enhance $\mathrm{HCV}$ pathogenicity. ${ }^{18}$

\section{REFERENCES}

1. Hnatyszyn HJ. Chronic hepatitis $\mathrm{C}$ and genotyping. The clinical significance of determining HCV genotypes. Antivir Ther 2005 Jan;10(1):1-11.

2. Mohamed MK. Epidemiology of HCV in Egypt 2004. Afro Arab Liver J 2004;13(2):41-52.

3. Global Burden of Hepatitis C Working Group. Global burden of disease (GBD) for hepatitis C. J Clin Pharmacol 2004 Jan;44(1):20-29.

4. Isom HC, McDevitt EI, Moon MS. Elevated hepatic iron: a confounding factor in chronic hepatitis C. Biochim Biophys Acta 2009 Jul;1790(7):650-662.

5. Bonkovsky HL, Naishadham D, Lambrecht RW, Chung RT, Hoefs JC, Nash SR, Rogers TE, Banner BF, Sterling RK, Donovan JA, et al. Roles of iron and HFE mutations on severity and response to therapy during retreatment of advanced chronic hepatitis C. Gastroenterology 2006 Nov;131(5): 1440-1451.

6. Hofer H, Osterreicher C, Jessner W, Penz M, Steindl-Munda P, Wrba F, Ferenci P. Hepatic iron concentration does not predict response to standard and pegylated-IFN/ribavirin therapy in patients with chronic hepatitis C. J Hepatol 2004 Jun;40(6):1018-1022.

7. Bonkovsky HL, Troy N, McNeal K, Banner BF, Sharma A, Obando J, Mehta S, Koff RS, Liu Q, Hsieh CC. Iron and HFE or TfR1 mutations as comorbid factors for development and progression of chronic hepatitis C. J Hepatol 2002 Dec;37(6):848-854.

8. Ferrara F, Ventura P, Vegetti A, Guido M, Abbati G, Corradini E, Fattovich G, Ferrari C, Tagliazucchi M, Carbonieri A, et al. Serum ferritin as a predictor of treatment outcome in patients with chronic hepatitis C. Am J Gastroenterol 2009 Mar;104(3): 605-616.

9. Merryweather-Clarke AT, Pointon JJ, Jouanolle AM, Rochette J, Robson KJ. Geography of HFE C282Y and H63D mutations. Genet Test 2000 Feb;4(2):183-198.
10. Tung BY, Emond MJ, Bronner MP, Raaka SD, Cotler SJ, Kowdley KV. Hepatitis C, iron status, and disease severity: relationship with HFE mutations. Gastroenterology 2003 Feb;124(2):318-326.

11. Piperno A, FargionS, D'Alba R, Roffi L, Fracanzani AL, Vecchi L, Failla M, Fiorelli G. Liver damage in Italian patients with hereditary hemochromatosis is highly influenced by hepatitis B and C virus infection. J Hepatol 1992 Nov;16(3):364-368.

12. Di Bisceglie AM, Bonkovsky HL, ChopraS, FlammS, Reddy RK, Grace N, Killenberg P, Hunt C, Tamburro C, Tavill AS, et al. Iron reduction as an adjuvant to interferon therapy in patients with chronic hepatitis $C$ who have previously not responded to interferon: a multicenter, prospective, randomized, controlled trial. Hepatology 2000 Jul;32(1): 135-138.

13. Sini M, Sorbello O, Civolani A, Demelia L. Hemochromatosis gene mutations: prevalence and effects on pegylatedinterferon and ribavirin therapy response in chronic hepatitis C in Sardinia. J Clin Exp Hepatol 2012 Sep;2(3):211-217.

14. Coelho-Borges S, Cheinquer H, Cheinquer N, Krug L, Ashton-Prolla P. HFE mutations prevent sustained virological response to interferon plus ribavirin in chronic hepatitis C patients with serum markers of iron overload. Am J Gastroenterol 2002 Jun;97(6):1570-1572.

15. Li SH, Zhao H, Ren YY, Liu YZ, Song G, Ding P, Ding YP, Wang GQ. The H63D mutation of the hemochromatosis gene is associated with sustained virological response in chronic hepatitis $C$ patient treated with interferon based therapy: a meta analysis. Tohoku J Exp Med 2012 Apr;226(4):293-299.

16. Lebray P, Zylberberg H, Hue S, Poulet B, Carnot F, Martin S, Chretien Y, Pol S, Caillat-Zuckman S, Bréchot C, Nalpas B. Influence of HFE gene polymorphism on the progression and treatment of chronic hepatitis C. J Viral Hepat 2004 Mar;11(2):175-182.

17. Kakizaki S, Takagi H, Horiguchi N, Toyoda M, Takayama H, Nagamine T, Mori M, Kato N. Iron enhances hepatitis C virus replication in cultured human hepatocytes. Liver 2000 Apr;20(2):125-128.

18. Fracanzani AL, Conte D, Fraquelli M, Taioli E, Mattioli M, Losco A, Fargion S. Increased cancer risk in a cohort of 230 patients with hereditary hemochromatosis in comparison to matched control patients with non-iron-related chronic liver disease. Hepatology 2001 Mar;33(3):647-651. 